\title{
THE FOOD INSECURITY STATUS OF PASTORAL AND AGRO-PASTORAL HOUSEHOLDS IN ETHIOPIA
}

\author{
Eticha Abebe Abera*, Ahmed Endris Mossa** \\ *Action Aid Ethiopia, Seba Boru Woreda, Gujii Zone, Oromia National Regional State, Ethiopia \\ ** Bahir Dar University, Bahir Dar, Ethiopia
}

corresponding author: Ahmed Endris Mossa, e-mail: yemusa@yahoo.com

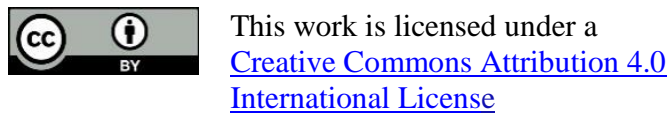

\author{
Original scientific paper \\ Received: November $19^{\text {th }}, 2019$ \\ Accepted: January $18^{\text {th }}, 2020$ \\ HAE-1931 \\ https://doi.org/10.33765/thate.10.4.1
}

\begin{abstract}
Understanding the major causes of food insecurity is important for interventions aiming at minimizing food insecurity. Therefore, this study was conducted to assess the status of food insecurity of pastoral and agro-pastoral households of Seba Boru Woreda Guji Zone, Oromia National Regional State, Ethiopia. In order to achieve these objectives, 112 respondents' agro pastoralists were selected from 2 kebeles (the smallest administrative unit). To this end, both probabilities (stratified, systematic and random) and non-probability (purposive) sampling techniques were employed. Primary and secondary data were collected from various sources. The data were analysed using descriptive statistics like mean standard deviation, percentage and frequency distributions. Univariate analysis such as t-test and chi-square $\left(\chi^{2}\right)$ were also used to describe the characteristics of food secured and food insecure groups. The survey result shows that about $60(53.7 \%)$ of sample respondents were food insecure while only $52(46.3 \%)$ were food secure. As per a binary logistic model regression, four variables such as family size, land, income, and extension service were significant at $10 \%$ probability levels. Finally, limiting population size through integrated health and education service, intensification of agriculture through extension service by strengthening PTC (pastoral training center), are some to recommend to curb food insecurity in the area.
\end{abstract}

Keywords: food insecurity, pastoral and agro-pastoral household, Ethiopia

\section{INTRODUCTION}

Lack of food is a more pervasive and persistent problem in Africa than in any other continent today. A large proportion of the African population is increasingly subject to extreme food shortages and chronic food insecurity. In sub-Saharan Africa (SSA) the number of people living on less than 1 US\$ per day was almost doubled between 1981 and 2001, rising from 164 million to 313 million people. This indicates that the proportion of the population subsisting below the poverty line (1.25 US\$ per day) remain unchanged [1]. 
Smallholder agriculture is the most important sector of Ethiopia's economy. More than $80 \%$ of the populations live in rural areas and their main source of income is agriculture. Though the agricultural sector accounts for about $45 \%$ of GDP (Gross Domestic Product), almost 90 $\%$ of exports, and $85 \%$ of employment, food insecurity remains key challenge [2]. According to the 2014 Human development report of the United Nations development program, Ethiopia ranked $173^{\text {rd }}$ out of 187 countries in the human development index, with a GDP per capita adjusted with the Purchasing Power Parity of only 779 US\$ compared to almost 2000 US\$ average for Sub-Saharan countries [3].

Chronic food insecurity has been a defining feature of the poverty that has affected millions of Ethiopians for decades. The vast majority of these extraordinarily poor households live in rural areas that are heavily reliant on rain-fed agriculture. Thus, in years of poor rainfall, the threat of widespread starvation is high. Merely in 2002/03, the number of people who faced food shortage and were affected by famine reached as high as 14.3 million, nearly a quarter of the country's population [4]. The same source indicated that the country has never been sufficient to enable the rural population to be food secure in the last three decades. Given the current rapid population growth $(2.6 \%)$, food production has to increase at 5 to $6 \%$ per annum to meet the ever growing food demand of the country estimated at $2100 \mathrm{kcal}$ per day per adult equivalent or $225 \mathrm{~kg}$ of food grain per adult equivalent per year.

The poor performance of agricultural production for several years could not adequately feed its population from domestic production. This manifested itself in the prevalence of food insecurity, both chronic and transitory, which has almost become a structural phenomenon that affects the way of life for a large proportion of the population of the country [5].

Food insecurity is common feature in Guji Zone of Oromia National Regional State. The food insecurity stress places undue pressure on already weak communities that are struggling to sustain their herds of livestock and cultivate their lands. During high stress periods, the natural resources base (water and pasture) becomes completely insufficient to support the existing livestock population; consequently, many animals die or are left at a situation where they cannot provide enough milk and other products to sustain the livelihood. This, coupled with lack of any appreciable harvests of food crops, leads to famine, malnutrition, poor health, and high mortality of people and livestock during droughts. Mostly affected are women and children. Recovery from food insecurity is hard because the problem leaves household assets critically depleted.

Food self-sufficiency has remained the stated goal of the Ethiopian government. But, the problem of food security has continued to persist in the country [6]. Studies were conducted on food security with the context of specific places (locations), like the one on the indigenous coping strategies in the face of famine, i.e. the case of Borana Oromo that is worth mentioning [7].

Therefore, there is a need to comprehensively address the problem of food insecurity in the country through conducting wider and indepth studies to indicate the policy direction to solve food insecurity challenges. Hence, this study intends to analyse the extent of food insecurity through clearly identifying specific determining factors that pertain to the study area. Therefore, it presumes to narrow the existing information gap (study area context) and to capitalize on the existing ones which contribute for proper policy designing.

\section{EXPERIMENTAL}

\section{The study area}

Seba Boru is among the 15 administrative woredas, or districts, of Guji zone, Oromia National Regional State, Ethiopia (Figure 1). The total population of Seba Boru woreda is 
estimated to reach 107536 including 2 urban populations in 2010/2011, projected based on the 2007 national population and housing census. Out of the total population, 60844 $(56.58 \%)$ are males and the remaining 46692 $(43.41 \%)$ are females [8]. Its capital town is Derme, located at distance of $589 \mathrm{~km}$ South East from Addis Ababa and $220 \mathrm{~km}$ North West of Negellee, the capital of Guji zone. It shares the boundary with Shakkiso woreda in north, Arero woreda in south, Goro Dola \& Wadara woredas in east, and Malka Soda woreda in west. According to data obtained from district pastoral development office, it covers an area about $9233 \mathrm{~km}^{2}$ of land. It is organized into 24 kebeles and 2 urban kebeles. Among these kebeles, 9 of them are agropastoral (engaged both on crop and livestock farming) the rest are pure pastoralist \& urban dwellers. The projected population size in 2011 is 108094 of which 64178 are male and 53916 are female. The average family size is 7.

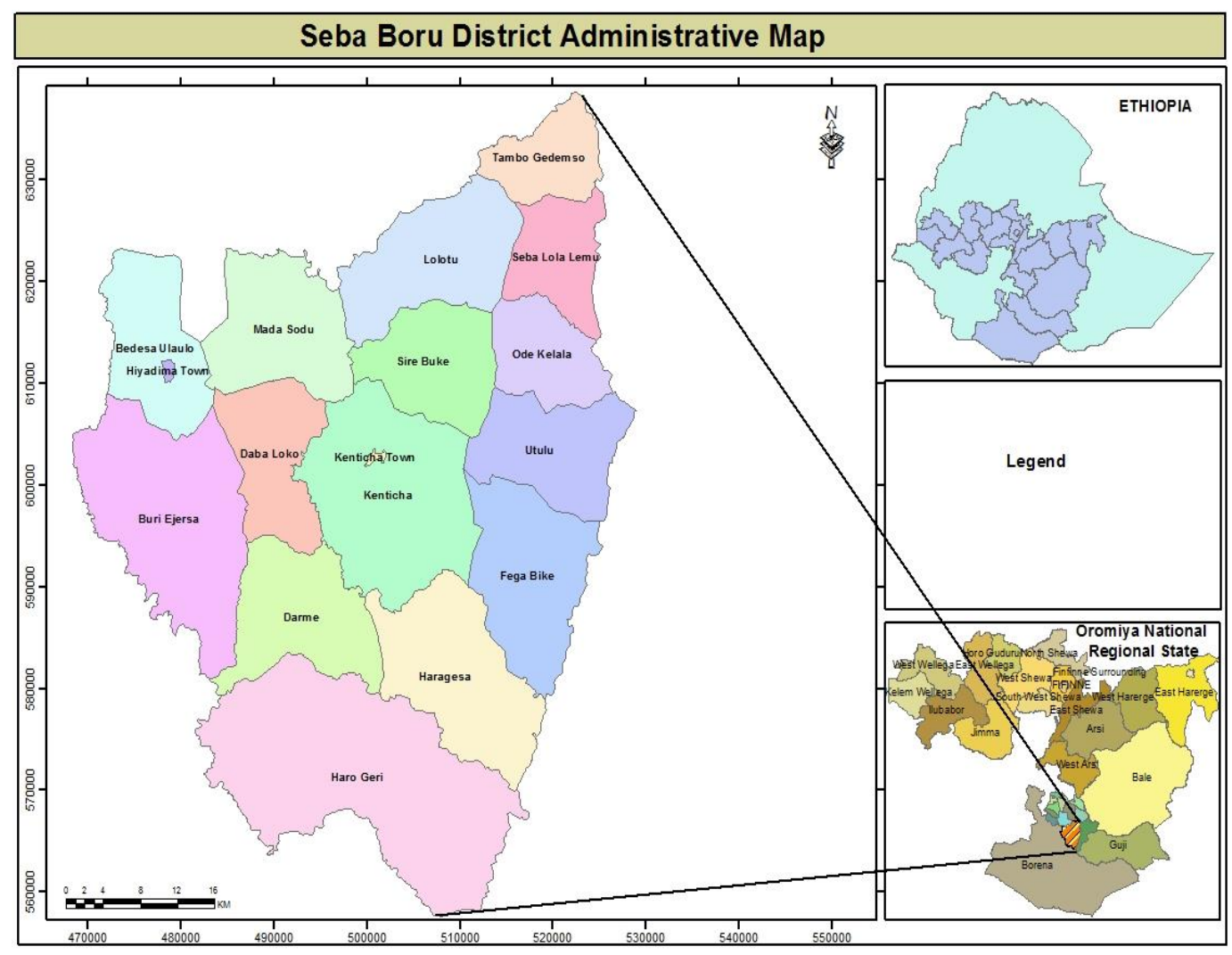

Figure 1. Map of the study area [9]

\section{Data Collection}

Both primary and secondary data were used for this study. The primary data were collected from scientifically selected sample households and focus groups in the study area using structured questionnaire and checklists while the secondary data were collected from different published and unpublished sources using electronic medias and contacting relevant offices. The primary data were collected from about 22 female and 90 male headed households.

\section{Data Analysis}

In this study both descriptive statistics and econometric models were employed to analyse the quantitative data. The descriptive results are based on mean, standard deviation and percentage depending on the nature of the data. To evaluate whether the significant difference is there or not between the food secured and insecure groups, different tests including t-test and chi-square tests were made for the continuous and discrete data types, respectively. Therefore, econometric model 
(logit model) was used to further identify the importance of household attributes and socio economic factors on household food security status.

The dependent variable is the status of household in terms of food secured and food insecure (cut-off point) $2200 \mathrm{kcal} /$ day/AE (Adult equivalent). Food security status of the study area is computed through the analysis of quantitative data collected on food consumption pattern of households. Accordingly, household found to consume less than the cut-off, $2200 \mathrm{kcal} / \mathrm{day} / \mathrm{AE}$ were considered as food insecure and households who consume equal or above $2200 \mathrm{kcal}$ were considered as food secure.

SPSS (Statistical package for social science) was used for data entry, cleaning and editing while the Stata software was employed to analyse the data to obtain both descriptive and econometric results as it is more advanced and preferred for the analysis purpose for the social studies.

\section{RESULTS AND DISCUSSION}

This section presents the descriptive analysis results of the main variables included in the econometric results and other important variables considered for the study of food security status.

\section{Descriptive analysis of variables included in econometric model}

As shown in Table 1, there is no significant mean difference in terms of demographic characteristics between the food secured and insecure households in the study area. The average family counts 7 members. However, when converted to both adult equivalent and man equivalent, the number is less for both groups. The result indicates that dependency ratio in the study area is nearly 2 , meaning that one economically active household member is responsible for another member in addition to him/herself. The average age of the sample household is about 38 and 37 years for food secured and insecure groups, respectively, implying that they are in the middle of economically active population which is suitable for farm activities. As far as the gender of the household is concerned, there is a significant difference between the 2 groups (chi2 $=3.2593)$. As revealed in Table 2, the result shows that more female-headed households are categorized in food secured group $(27 \%)$ than food insecure group $(13 \%)$ as compared to the male-headed households.

Table 3 shows the major productive asset ownership, household income, and access to market. The result indicates that the land areas owned by food secured household are significantly larger than the insecure group at $5 \%$ level of significance. Similarly, the amount of crop produced, sold and consumed from own production is significantly higher for the food secured households while there is no difference in terms of crop used for other purposes from own production. The result therefore implies that having more land and producing more crops positively contributes to food security in the pastoral and agro-pastoral areas similar to the highland areas. The result also shows that the food secured households owned significantly higher number of oxen and earned higher income generated from crop sale as compared to the food insecure groups during the year under consideration.

The descriptive result of important discrete variables included in the econometric variables is given in Table 4. The result shows no significant difference in terms of the dummy variables, i.e. engaged in crop production or not, having saving habit or not, having access to extension services or not, and having access to credit or not, among the two groups. In general, $75 \%, 96 \%, 60 \%$, and $92 \%$ of the overall sample households were engaged in crop production, received extension services, had saving habit and credit access, respectively, in 2015 cropping season in the study area. 
Table 1. Descriptive analysis of the demographic background of the sample household (HH) for the continuous variables

\begin{tabular}{|c|c|c|c|c|c|}
\hline & Total (112) & Food secured (52) & Food insecure (60) & \multirow{2}{*}{$\begin{array}{l}\text { Difference } \\
\text { in means }\end{array}$} & \multirow{2}{*}{$\mathrm{t}$-value } \\
\hline Variables & Mean (STD) & Mean (STD) & Mean (STD) & & \\
\hline $\begin{array}{c}\text { Family size in adult } \\
\text { equivalent (AE) }\end{array}$ & $2.45(1.170)$ & $2.34(1.010)$ & $2.55(1.294)$ & 0.104 & 0.24 \\
\hline Family size (FS) & $5.3(2.276)$ & $5.2(2.422)$ & $5.3(2.162)$ & 0.10 & 0.24 \\
\hline Family size (head count) & $7.0(2.630)$ & $7.1(2.766)$ & $7.0(2.527)$ & -0.185 & 0.369 \\
\hline Dependency Ratio (DR) & $1.9(1.424)$ & $1.9(1.210)$ & $1.9(1.597)$ & -0.007 & 0.01 \\
\hline Age of HH head & $37.7(14.584)$ & $38.1(13.884)$ & $37.4(15.274)$ & -0.663 & -0.24 \\
\hline Education of HH head & $2.1(2.777)$ & $2.4(2.960)$ & $1.9(2.604)$ & -0.559 & -1.06 \\
\hline
\end{tabular}

Table 2. Descriptive analysis of gender of the household head

\begin{tabular}{|c|c|c|c|c|c|c|c|}
\hline \multirow{2}{*}{ Sex } & \multicolumn{2}{|c|}{ Food secured } & \multicolumn{2}{c|}{ Food insecure } & \multicolumn{2}{|c|}{ Total } & \multirow{2}{*}{ chi2 (p-value) } \\
\cline { 2 - 8 } & frequency & $\%$ & frequency & $\%$ & frequency & $\%$ & \\
\hline Male & 38 & 73 & 52 & 87 & 90 & 80 & \multirow{3}{*}{$3.2593(0.07)$} \\
\hline Female & 14 & 27 & 8 & 13 & 22 & 20 & \\
\hline Total & 52 & 100 & 60 & 100 & 112 & 100 & \\
\hline
\end{tabular}

Table 3. Descriptive analysis of asset ownership, income and access to market of the sample household for the continuous variables

\begin{tabular}{|c|c|c|c|c|c|}
\hline & Total (112) & Food secured (52) & Food insecure (60) & \multirow{2}{*}{$\begin{array}{l}\text { Difference } \\
\text { in means }\end{array}$} & \multirow{2}{*}{ t-value } \\
\hline Variables & Mean (STD) & Mean (STD) & Mean (STD) & & \\
\hline Land owned (ha) & $1.8(1.927)$ & $2.3(2.193)$ & $1.4(1.582)$ & -0.832 & $-2.32^{* *}$ \\
\hline Crop produced (qt) & $7.7(10.105)$ & $10.3(11.83)$ & $5.53(7.775)$ & -4.739 & $-2.54^{* *}$ \\
\hline Crop sold (qt) & $2.12(4.388)$ & $3.48(5.369)$ & $0.93(2.871)$ & -2.547 & $-3.2^{* * *}$ \\
\hline $\begin{array}{l}\text { Crop consumed from } \\
\text { production }(\mathrm{qt})\end{array}$ & $5.57(6.652)$ & $6.74(7.674)$ & $4.55(5.484)$ & -2.190 & $-1.75^{*}$ \\
\hline $\begin{array}{c}\text { Crop used for } \\
\text { other purposes }(q t)\end{array}$ & $0.03(0.212)$ & $0.02(0.142)$ & $0.03(0.258)$ & 0.009 & 0.23 \\
\hline Number of oxen & $1.06(1.139)$ & $1.48(2.372)$ & $0.70(1.139)$ & -0.781 & $-2.27^{* * *}$ \\
\hline Livestock owned (TLU) & $8.7(8.743)$ & $9.6(8.137)$ & $7.8(9.225)$ & -1.762 & -1.06 \\
\hline Livestock sold (TLU) & $0.96(1.807)$ & $0.86(1.307)$ & $1.06(2.155)$ & 0.197 & 0.57 \\
\hline Livestock died (TLU) & $0.85(1.512)$ & $0.85(1.335)$ & $0.86(1.661)$ & 0.008 & 0.03 \\
\hline Income from crop (Birr) & $1464(3175)$ & 2337 (3783) & 709 (2312) & -1628 & $-2.79^{* * * *}$ \\
\hline Livestock income (Birr) & 5334 (10476) & $4997(8209)$ & $5626(12167)$ & 628 & 0.32 \\
\hline Off-farm income (Birr) & $1512(6630)$ & $1732(8212)$ & $1322(4933)$ & -409 & -0.32 \\
\hline Distance to market $(\mathrm{km})$ & $27.2(17.2)$ & $25.9(18.9)$ & $28.4(15.7)$ & 2.586 & 0.79 \\
\hline
\end{tabular}

$\mathrm{qt}=$ quintals $=100 \mathrm{~kg}$

means significant at $10 \%, 5 \%$ and $1 \%$, respectively 
Table 4. Descriptive analysis of access to services and saving habits of the sample household for the discrete variables

\begin{tabular}{|c|c|c|c|c|c|c|c|c|}
\hline \multirow{2}{*}{$\begin{array}{c}\text { Discrete } \\
\text { variables }\end{array}$} & \multirow{2}{*}{ Response } & \multicolumn{2}{|c|}{ Food secured } & \multicolumn{2}{|c|}{ Food insecure } & \multicolumn{2}{|c|}{ Total } & \multirow[t]{2}{*}{ chi2 (p-value) } \\
\hline & & frequency & $\%$ & frequency & $\%$ & frequency & $\%$ & \\
\hline \multirow{3}{*}{$\begin{array}{l}\text { Engaged in } \\
\text { crop } \\
\text { production }\end{array}$} & Yes & 39 & 75 & 48 & 80 & 87 & 78 & \multirow{3}{*}{$0.402(0.526)$} \\
\hline & No & 13 & 25 & 12 & 20 & 25 & 22 & \\
\hline & total & 52 & 100 & 60 & 100 & 112 & 100 & \\
\hline \multirow{3}{*}{$\begin{array}{c}\text { Extension } \\
\text { service }\end{array}$} & Yes & 50 & 96 & 53 & 88 & 103 & 92 & \multirow{3}{*}{$2.306(0.129)$} \\
\hline & No & 2 & 4 & 7 & 12 & 9 & 8 & \\
\hline & total & 52 & 100 & 60 & 100 & 112 & 100 & \\
\hline \multirow{3}{*}{ Saving habit } & Yes & 31 & 60 & 20 & 33 & 41 & 37 & \multirow{3}{*}{$0.597(0.44)$} \\
\hline & No & 21 & 40 & 40 & 67 & 71 & 63 & \\
\hline & Total & 52 & 100 & 60 & 100 & 112 & 100 & \\
\hline \multirow{3}{*}{$\begin{array}{l}\text { Credit } \\
\text { access }\end{array}$} & Yes & 48 & 92 & 58 & 97 & 106 & 95 & \multirow{3}{*}{$1.044(0.307)$} \\
\hline & No & 4 & 8 & 2 & 3 & 6 & 5 & \\
\hline & total & 52 & 100 & 60 & 100 & 112 & 100 & \\
\hline
\end{tabular}

\section{Food security status of sample households}

\section{Calorie intake of the sample households}

Food security status of the sample household has been assessed using the weekly consumption of the sample households during the study time. To evaluate the food security status, the weekly calorie intake per household was converted to the per capita daily calorie intake per adult equivalent. Table 5 shows that there is a significant difference between the food secured and insecure groups in terms of both weekly consumption per household and daily per capita calorie intake in the study area. On average, the per capita calorie intake per adult equivalent of the food secured group is $3416 \mathrm{kcal}$, while that of insecure group is only $1349 \mathrm{kcal}$ during the time of consideration in the study area. The daily per capita calorie intake of the food insure group is by far lower than the cut-off point of $2200 \mathrm{kcal}$ while that of food secured one is by far higher than this point.

Table 6 reveals the daily energy consumption in kcal per adult equivalent of sample households. The result shows that the minimum, maximum and average per capita per $\mathrm{AE}$ is 464, 7688 and $2308 \mathrm{kcal}$ respectively, for the overall sample. It also indicates that, out of the total $54 \%$ of the food insecure group, more proportion of the food insecure group $(32 \%)$ falls in the lowest level of less than $1500 \mathrm{kcal}$ per day per adult equivalent. Similarly, out of the $46 \%$ of the total food secured groups, more proportion of the food secured group ( $35 \%$ ) is also situated in the category of $2200-3999 \mathrm{kcal}$ per adult equivalent per day.

Consumption practices by different category of household members under different conditions

Tables 7 - 10 reveal the number of meals per day consumed by different categories of household members including children below 5 , between age of 6 to 17, adult of age 18 to 64 and elders of age above 64 during the year under consideration at normal time and at a time of difficulties of obtaining food. As revealed in Table 7 , all children below 5 years of age in both the food secured and insecure households eat at least twice a day during the normal time. However, under the same condition, children from the food secured group eat up to 5 times a day while none of the children of food insecure group eat 5 times a day during the normal time. During the time of difficulty, children of all groups eat a maximum of 3 times a day and a minimum of only once, which is very difficult for children to eat only once in 24 hours. 
Table 5. Weekly and daily food consumption status of the sample households (in kcal)

\begin{tabular}{|c|c|c|c|c|c|}
\hline Variables & Total (112) & Food secured (52) & Food insecure (60) & \multirow{2}{*}{$\begin{array}{l}\text { Difference } \\
\text { in means }\end{array}$} & \multirow{2}{*}{$\mathrm{t}$-value } \\
\hline & Mean (STD) & Mean (STD) & Mean (STD) & & \\
\hline $\begin{array}{c}\text { Weekly food } \\
\text { consumption per } \\
\text { household (kcal) }\end{array}$ & 37248 (25289) & 53105 (25549) & $23506(15009)$ & - 29599 & $-7.59^{* * *}$ \\
\hline $\begin{array}{l}\text { Daily per capita food } \\
\text { consumption per AE } \\
(\mathrm{kcal})\end{array}$ & 2308 (1378) & 3416 (1233) & 1349 (489) & -2067 & $-11.95^{* * *}$ \\
\hline
\end{tabular}

Number in the parenthesis is standard deviation; ${ }^{* * *}$ means significant at $1 \%$

Table 6. Daily energy consumption in kcal per AE of sample households

\begin{tabular}{|c|c|c|c|}
\hline Category & $\begin{array}{c}\text { Consumption } \\
\text { in kcal }\end{array}$ & Number & Present \\
\hline \multirow{4}{*}{ Food insecure households } & $<1500$ & 36 & 32 \\
\cline { 2 - 4 } & $1500-1799$ & 12 & 11 \\
\cline { 2 - 4 } Food secured households & $1800-2199$ & 12 & 11 \\
\hline & $\begin{array}{c}2200 \text { and above in } \\
\text { general }\end{array}$ & 52 & 46 \\
\cline { 2 - 4 } & $2200-3999$ & 39 & 35 \\
\cline { 2 - 4 } & 4000 and above & 13 & 11 \\
\hline \multirow{5}{*}{} & Min. & 464 & \\
\cline { 2 - 4 } & Max. & 7688 & \\
\cline { 2 - 4 } & Mean & 2308 & \\
\cline { 2 - 4 } & Total & 112 & \\
\hline
\end{tabular}

Table 7. Meals per day for children below the age of 5 at normal time and time of difficulties

\begin{tabular}{|c|c|c|c|c|c|c|c|c|c|c|c|c|}
\hline & \multicolumn{3}{|c|}{ Food secured } & \multicolumn{3}{c|}{ Food insecure } & \multicolumn{4}{c|}{ Total } \\
\hline Meals/day & $\begin{array}{c}\text { Normal } \\
\text { time }\end{array}$ & \multicolumn{2}{c}{$\begin{array}{c}\text { Time of } \\
\text { difficulty }\end{array}$} & \multicolumn{2}{c|}{$\begin{array}{c}\text { Normal } \\
\text { time }\end{array}$} & \multicolumn{2}{c|}{$\begin{array}{c}\text { Time of } \\
\text { difficulty }\end{array}$} & \multicolumn{2}{|c|}{$\begin{array}{c}\text { Normal } \\
\text { time }\end{array}$} & \multicolumn{2}{c|}{$\begin{array}{c}\text { Time of } \\
\text { difficulty }\end{array}$} \\
\hline & No & $\%$ & No & $\%$ & No & $\%$ & No & $\%$ & No & $\%$ & No & $\%$ \\
\hline 1 & & & 2 & 4 & & & 3 & 5 & & & 5 & 5 \\
\hline 2 & 14 & 29 & 43 & 88 & 12 & 21 & 47 & 83 & 26 & 25 & 90 & 85 \\
\hline 3 & 34 & 69 & 4 & 8 & 41 & 72 & 7 & 12 & 75 & 71 & 11 & 10 \\
\hline 4 & 1 & 2 & & & 3 & 5 & & & 4 & 4 & & \\
\hline 5 & 1 & 2 & & & 0 & 0 & & & 1 & 1 & & \\
\hline
\end{tabular}

Table 8. Number of meals per day for children between the age of 6 and17 at normal time and time of difficulties

\begin{tabular}{|c|c|c|c|c|c|c|c|c|c|c|c|c|}
\hline & \multicolumn{3}{|c|}{ Food secured (52) } & \multicolumn{3}{c|}{ Food Insecure (60) } & \multicolumn{4}{c|}{ Total (112) } \\
\hline Meals/day & $\begin{array}{c}\text { Meals/day } \\
\text { at normal } \\
\text { time }\end{array}$ & $\begin{array}{c}\text { Meals/day } \\
\text { at time of } \\
\text { difficulty }\end{array}$ & $\begin{array}{c}\text { Meals/day } \\
\text { at normal } \\
\text { time }\end{array}$ & $\begin{array}{c}\text { Meals/day } \\
\text { at time of } \\
\text { difficulty }\end{array}$ & $\begin{array}{c}\text { Meals/day } \\
\text { at normal } \\
\text { time }\end{array}$ & $\begin{array}{c}\text { Meals/day } \\
\text { at time of } \\
\text { difficulty }\end{array}$ \\
\hline & No & $\%$ & No & $\%$ & No & $\%$ & No & $\%$ & No & $\%$ & No & $\%$ \\
\hline 1 & & & 6 & 12.2 & & & 13 & 22.8 & & & 19 & 17.9 \\
\hline 2 & 18 & 36.7 & 41 & 71.9 & 25 & 43.9 & 41 & 83.7 & 43 & 40.6 & 82 & 77.4 \\
\hline 3 & 31 & 63.3 & 2 & 4.1 & 32 & 56.1 & 3 & 5.3 & 63 & 59.4 & 5 & 4.7 \\
\hline
\end{tabular}


Table 9. Number of meals per day for adults between the age of 18 and 64 at normal time and time of difficulties

\begin{tabular}{|c|c|c|c|c|c|c|c|c|c|c|c|c|}
\hline \multirow{3}{*}{ Meals/day } & \multicolumn{3}{|c|}{ Food secured (52) } & \multicolumn{3}{c|}{ Food Insecure (60) } & \multicolumn{4}{c|}{ Total (112) } \\
\cline { 2 - 13 } & $\begin{array}{c}\text { Meals/day } \\
\text { at normal } \\
\text { time }\end{array}$ & \multicolumn{2}{c|}{$\begin{array}{c}\text { Meals/day } \\
\text { at time of } \\
\text { difficulty }\end{array}$} & \multicolumn{2}{c|}{$\begin{array}{c}\text { Meals/day } \\
\text { at normal } \\
\text { time }\end{array}$} & \multicolumn{2}{c|}{$\begin{array}{c}\text { Meals/day } \\
\text { at time of } \\
\text { difficulty }\end{array}$} & $\begin{array}{c}\text { Meals/day } \\
\text { at normal } \\
\text { time }\end{array}$ & $\begin{array}{c}\text { Meals/day } \\
\text { at time of } \\
\text { difficulty }\end{array}$ \\
\cline { 2 - 14 } & No & $\%$ & No & $\%$ & No & $\%$ & No & $\%$ & No & $\%$ & No & $\%$ \\
\hline 1 & & & 9 & 18 & & & 24 & 41 & & & 33 & 30 \\
\hline 2 & 21 & 41 & 39 & 77 & 35 & 59 & 33 & 56 & 56 & 51 & 72 & 66 \\
\hline 3 & 29 & 55 & 3 & 6 & 24 & 41 & 2 & 3 & 53 & 48 & 5 & 4 \\
\hline 4 & 1 & 2 & & & & & & & 1 & 1 & & \\
\hline
\end{tabular}

Table 10. Number of meals per day for elderly above the age of 64 at deficit time

\begin{tabular}{|c|c|c|c|c|c|c|c|c|c|c|c|c|}
\hline \multirow{3}{*}{ Meals/day } & \multicolumn{4}{|c|}{ Food secured (52) } & \multicolumn{4}{|c|}{ Food Insecure (60) } & \multicolumn{4}{|c|}{ Total (112) } \\
\hline & \multicolumn{2}{|c|}{$\begin{array}{c}\text { Meals/day } \\
\text { at normal } \\
\text { time }\end{array}$} & \multicolumn{2}{|c|}{$\begin{array}{l}\text { Meals/day } \\
\text { at time of } \\
\text { difficulty }\end{array}$} & \multicolumn{2}{|c|}{$\begin{array}{l}\text { Meals/day } \\
\text { at normal } \\
\text { time }\end{array}$} & \multicolumn{2}{|c|}{$\begin{array}{l}\text { Meals/day } \\
\text { at time of } \\
\text { difficulty }\end{array}$} & \multicolumn{2}{|c|}{$\begin{array}{l}\text { Meals/day } \\
\text { at normal } \\
\text { time }\end{array}$} & \multicolumn{2}{|c|}{$\begin{array}{l}\text { Meals/day } \\
\text { at time of } \\
\text { difficulty }\end{array}$} \\
\hline & No & $\%$ & No & $\%$ & No & $\%$ & No & $\%$ & No & $\%$ & No & $\%$ \\
\hline 1 & 2 & 29 & 2 & 29 & 0 & 0 & 2 & 27 & 2 & 14 & 4 & 29 \\
\hline 2 & 1 & 14 & 5 & 57 & 5 & 71 & 4 & 71 & 6 & 43 & 9 & 64 \\
\hline 3 & 4 & 57 & 1 & 7 & 2 & 29 & 0 & 7 & 6 & 43 & 1 & 14 \\
\hline
\end{tabular}

Table 8 presents the number of meals per day for children between the age of 6 and 17 at normal time and at a time of difficulties during the past one year. The result indicated that these groups of household member obtain a maximum of three times and a minimum of two times at a normal time for both groups. More than half of both groups obtain a meal three times a day which is acceptable in Ethiopian condition, where three meals breakfast, lunch, and dinner - are secured. However, during the time of difficulty, only about $5 \%$ of the children between the ages of 6 to 17 can obtain three meals a day. A larger proportion of the food insecure households $(22.8 \%)$ eats only once in 24 hours as compared to $12 \%$ of the food secures groups.

The result shows that there is a significant variation in terms of the proportion of households obtaining their daily meals between the two groups at a time of difficulty (chi2 $=6.973$, which is significant at $5 \%$ ) for adult household members while there is no significant difference for children of both groups. That means that children are given focus at the expense of adults even in the households of food insecure groups. As shown in Table 9, about $41 \%$ and $18 \%$ of the adult household members of food insecure and secure groups, respectively, eat only once a day during a time of difficulty in the study area. Elders eat one to three times a day in the study area (Table 10). The result shows that, at a normal time, larger proportions of the elders (about $57 \%$ ) of food secured household obtain three times a day while a smaller proportion (about $29 \%$ ) of food insecure groups eats three times a day. The result is significantly different at $10 \%(\operatorname{chi} 2=5.333)$.

\section{Household food insecurity access scale assessment}

Table 11 presents the sample households food insecurity access scale (HFIAS) focusing on food consumption for the past 12 months in the study area. The result reveals that $31 \%$ and $19 \%$ of the of the food secured households, respectively, have never worried for not having enough food for the last 12 months, while only $18 \%$ and $15 \%$ of the food insecure group reported similar, respectively. On the other hands, most of the food insecure group $(35 \%)$ often worried for not having enough food for the last 12 months as compared with the food secured group (15\%). The result is significantly different at $10 \%$. 
Table 11. Percentage of sample households responded as "Yes" for the food insecurity access scale questions that focus on food consumption for family need in the last 12 months

\begin{tabular}{|c|c|c|c|c|c|c|c|c|c|}
\hline \multirow{2}{*}{$\begin{array}{l}\text { Questions/Responses and household } \\
\text { category (food secured and food insecure) }\end{array}$} & \multicolumn{2}{|c|}{ Never } & \multicolumn{2}{|c|}{ Rarely } & \multicolumn{2}{|c|}{ Sometimes } & \multicolumn{2}{|c|}{ Often } & \multirow{2}{*}{ chi2 } \\
\hline & $\begin{array}{l}\mathrm{FS} \\
(\%)\end{array}$ & $\begin{array}{l}\mathrm{FI} \\
(\%)\end{array}$ & $\begin{array}{l}\text { FS } \\
(\%)\end{array}$ & $\begin{array}{l}\text { FI } \\
(\%)\end{array}$ & $\begin{array}{l}\mathrm{FS} \\
(\%)\end{array}$ & $\begin{array}{c}\text { FI } \\
(\%)\end{array}$ & $\begin{array}{l}\mathrm{FS} \\
(\%)\end{array}$ & $\begin{array}{c}\text { FI } \\
(\%)\end{array}$ & \\
\hline $\begin{array}{l}\text { Did you worry that your household would } \\
\text { not have enough food? }\end{array}$ & 31 & 18 & 19 & 15 & 35 & 32 & 15 & 35 & $6.294^{*}$ \\
\hline $\begin{array}{l}\text { Were you or any household member not } \\
\text { able to eat the kinds of foods that you } \\
\text { preferred because of a lack of resources? }\end{array}$ & 12 & 10 & 25 & 17 & 52 & 35 & 12 & 38 & $10.6^{* *}$ \\
\hline $\begin{array}{l}\text { Did you or any household member eat just } \\
\text { a few kinds of food day after day due to a } \\
\text { lack of resources? }\end{array}$ & 31 & 15 & 21 & 18 & 35 & 32 & 14 & 35 & $8.46^{* *}$ \\
\hline $\begin{array}{l}\text { Did you or any household member eat } \\
\text { food that you preferred not to eat because } \\
\text { of lack of resources? }\end{array}$ & 31 & 17 & 21 & 13 & 23 & 28 & 25 & 42 & 5.97 \\
\hline $\begin{array}{l}\text { Did you/any household member eat a } \\
\text { smaller meal than you felt you needed } \\
\text { because there was not enough food? }\end{array}$ & 23 & 17 & 25 & 15 & 31 & 35 & 21 & 33 & 3.645 \\
\hline $\begin{array}{l}\text { Did you/any household member eat fewer } \\
\text { meals in a day because there was not } \\
\text { enough food (once a day)? }\end{array}$ & 31 & 20 & 35 & 28 & 21 & 28 & 14 & 23 & 3.666 \\
\hline $\begin{array}{l}\text { Was there ever no food at all in your } \\
\text { household because there were no } \\
\text { resources to get more? }\end{array}$ & 25 & 15 & 35 & 40 & 32 & 13 & 6 & 0 & 3.330 \\
\hline $\begin{array}{l}\text { Did you or any household member go to } \\
\text { sleep hungry because there was not } \\
\text { enough food? }\end{array}$ & 39 & 25 & 25 & 25 & 21 & 27 & 15 & 23 & 2.863 \\
\hline $\begin{array}{l}\text { Did you/any household member go a } \\
\text { whole day without eating anything } \\
\text { because there was not enough food? }\end{array}$ & 44 & 35 & 27 & 38 & 19 & 12 & 10 & 15 & 3.398 \\
\hline
\end{tabular}

Note: Rarely, sometimes, and often means 1 to 2 months; 3 to 10 months and more than 10 months during the last year, respectively; FS and FI means food secured and food insecure groups respectively; ${ }^{*}$ and ${ }^{* *}$ means significant at $10 \%$ and $5 \%$, respectively.

The result also indicated that a significantly higher proportion $(25 \%)$ of the food secured households reported that they or members of their families were not able to eat the kinds of foods that they preferred because of a lack of resources as compared to the food insecure groups (17\%). Similarly, a significantly larger proportion of the food secure households (52 $\%)$ reported that they or their family member(s) were sometimes not able to eat the kinds of foods that they preferred because of a lack of resources as compared to their counterparts $(35 \%)$. On the other hands, a significantly higher proportion $(38 \%$ ) of the food secured households reported that they or their family member were often not able to eat the kinds of foods they preferred because of a lack of resources as compared to the food secured households $(12 \%)$ for the past 12 months.

Another important result depicted in Table 11 is that the significantly higher proportion (31 $\%)$ and the smaller proportion (14\%) of the food secure households reported that they or their family member rarely and often ate just a 
few kinds of food day after day due to a lack of resources, respectively as compared to their counterparts who reported that $15 \%$ and $35 \%$ of them ate just a few kinds of food day after day due to a lack of resources, respectively for the past 12 months. The result reveals that 35 $\%$ and $32 \%$ of the food secured and food insecure groups responded that they sometimes ate just a few kinds of food day after day due to a lack of resources, respectively for the last 12 months. The result depicted that the proportion of the households responded the worst cases (that is the households often go to sleep hungry because there was not enough food and go a whole day without eating anything because there was not enough food) is less for both food secured groups and insecure groups for the past 12 months.

Table 12 presents the sample households food insecurity access scale (HFIAS) for the past 12 months including non-food consumption in the study area. As indicated in Table 12, based on the respondents own assessment of the adequacy of their family's food consumption from their own food production over the past 12 months, $80 \%$ of the food insecure groups and $64 \%$ of the food secured groups have less than adequate food while $33 \%$ of the food secured and $17 \%$ of the food insecure group had adequate food, and only $3 \%$ of each group had more than enough food. It also reveals that taking into consideration all food sources (own production + food purchase + help from different sources + food hunted from forests and lakes), the respondents own assessment result shows that their family's food consumption in the past 12 months was more of less than adequate for both groups although the proportion was significantly higher $(70 \%)$ for the food insecure groups as compared to the food secured $(35 \%)$ groups.

Non-food utilization status of the sample households for housing, clothing, schooling and health was depicted in Table 12. The result shows that more proportion of the food insecure households had less than adequate access scale in terms of all mentioned variables as compared to the food secure groups. However, the difference was significant only for the access to clothing assessment for adequacy for the family members for the last 12 months.

\section{CONCLUSION}

This research tried to uncover the food security status of pastoral and agro-pastoral households in Seba Boru woreda of Oromia Regional State, Ethiopia. Out of the total of 112 sample households, $52(46.3 \%)$ are food secured while the rest $53.7 \%$ are food insecure and consuming less than 2200 $\mathrm{kcal} /$ day/adult in the study area. On average, the daily per capita calorie consumption of food secured groups is $3416 \mathrm{kcal}$ while that of food insecure group is $1349 \mathrm{kcal}$ based on the weekly consumption data collected during the field survey. Econometric analysis result shows that out of 17 variables, 4 of them, namely family size in adult equivalent, total land owned and used for different purposes, income from crop sale and access to extension services were found to influence the food security status of the sample households in the study area. Therefore, the family size converted to adult equivalent had a negative effect on food security status of the household. So, using family planning to make the family size balanced with the available resources as the long term strategy and ensuring adequate job for all active family members so that they generate income for their consumption and saving as both short term and long term strategies may help to improve the food security status in the study area. The former could be effective through awareness creation while the latter needs high investment in rural job opportunity creation. 
Table 12. Percentage of sample households responded as "Yes" for the food insecurity access scale questions including non-food consumption for family need in the last 12 months

\begin{tabular}{|c|c|c|c|c|c|c|c|}
\hline \multirow{2}{*}{$\begin{array}{c}\text { Questions/Responses and household category } \\
\text { (food secured and food insecure) }\end{array}$} & \multicolumn{2}{|c|}{$\begin{array}{c}\text { It was less than } \\
\text { adequate }\end{array}$} & \multicolumn{2}{|c|}{$\begin{array}{c}\text { It was just } \\
\text { adequate }\end{array}$} & \multicolumn{2}{|c|}{$\begin{array}{c}\text { It was more } \\
\text { than enough }\end{array}$} & \multirow{2}{*}{ chi 2} \\
\cline { 2 - 7 } & $\begin{array}{c}\text { FS } \\
(\%)\end{array}$ & $\begin{array}{c}\text { FI } \\
(\%)\end{array}$ & $\begin{array}{c}\text { FS } \\
(\%)\end{array}$ & $\begin{array}{c}\text { FI } \\
(\%)\end{array}$ & $\begin{array}{c}\text { FS } \\
(\%)\end{array}$ & $\begin{array}{c}\text { FI } \\
(\%)\end{array}$ & \\
\hline $\begin{array}{c}\text { What is your own assessment of the } \\
\text { adequacy of your family's food consumption } \\
\text { over the past 12 months? } \\
\text { from own production) }\end{array}$ & 64 & 80 & 33 & 17 & 3 & 3 & \multirow{2}{*}{$7.04^{*}$} \\
\hline $\begin{array}{c}\text { What is your own assessment of the } \\
\text { adequacy of your family's housing over the } \\
\text { past 12 months? }\end{array}$ & 58 & 77 & 39 & 23 & 4 & 0 & $5.89^{*}$ \\
\hline $\begin{array}{c}\text { What is your own assessment of the } \\
\text { adequacy of your family's clothing over the } \\
\text { past 12 months? }\end{array}$ & 64 & 78 & 33 & 20 & 4 & 2 & 3.10 \\
\hline $\begin{array}{c}\text { What is your own assessment of the } \\
\text { adequacy of the health care your family gets } \\
\text { over the past 12 months? }\end{array}$ & 64 & 80 & 35 & 20 & 2 & 0 & 4.43 \\
\hline $\begin{array}{c}\text { What is your own assessment of the } \\
\text { adequacy of your children's schooling over } \\
\text { the past 12 months? }\end{array}$ & 62 & 79 & 36 & 21 & 2 & 0 & 4.26 \\
\hline $\begin{array}{c}\text { Taking into consideration all food sources } \\
\text { (own production + food purchase + help } \\
\text { from different sources + food hunted from } \\
\text { forests and lakes) how would you assess your } \\
\text { family's food consumption in the past 12 } \\
\text { months? }\end{array}$ & 35 & 70 & 37 & 5 & 29 & 25 & $21^{* * *}$ \\
\hline
\end{tabular}

FS and FI means food secured and food insecure groups respectively; ${ }^{*}$ and ${ }^{* * *}$ means significant at $10 \%$ and $1 \%$, respectively.

\section{REFERENCES}

[1] UNCDF, 2007 Results-Oriented Annual Report, The United Nations Capital Development Fund, 2007.

[2] MOFED, Ethiopia: Sustainable Development and Poverty Reduction, Draft, Ministry of Finance and Economic Development, Addis Ababa, Ethiopia, 2010.

[3] FAO, The State of Food Insecurity in the World 2010: Addressing Food Insecurity in Protracted Crises, Food and Agriculture Organization of the United Nations, Rome, Italy, 2010.

[4] A.D. Beyene, Determinants of off-farm participation decision of farm households in Ethiopia, Agrekon: Agricultural Economics Research, Policy and Practice in Southern Africa 47(2008) 1, 140-161.

[5] FDRE, Dimensions and Causes of Food Insecurity, Ministry of Foreign Affairs, Addis Ababa, Ethiopia, 2002.

[6] A. Bogale, Land Degradation, Impoverishment and Livelihood Strategies of Rural Households in Ethiopia: Farmers' Perceptions and Policy Implications, Shaker Verlag GmbH, Germany, 2002.

[7] T. Gemechu, Indigenous Survival Strategies in the Face of Famine: The Case of Boorana Oromo, Southern 
Ethiopia, MSc. Thesis, Addis Ababa University, Addis Ababa, Ethiopia, 2002.

[8] CSA (Central Statistical Agency), Summary and statistical report of 2007 population and housing census, Population Size by Age and Sex, Addis Ababa, Ethiopia, 2008.

[9] Seba Boru Woreda Information Office. 